IJIET, e-ISSN 2548-8430, p-ISSN 2548-8422, Vol. 2, No. 1, January 2018

International Journal of Indonesian Education and Teaching http://e-journal.usd.ac.id/index.php/IJIET

Sanata Dharma University, Yogyakarta, Indonesia

\title{
IMPLEMENTATION OF PROBLEM-BASED LEARNING MODEL (PBL) BASED ON REFLECTIVE PEDAGOGY APPROACH ON ADVANCED STATISTICS LEARNING
}

\author{
Niluh Sulistyani \\ Sanata Dharma University, Yogyakarta, Indonesia \\ niluh@usd.ac.id \\ https://doi.org/10.24071/ijiet.v2i1.952 \\ received 25 August 2017; revised 21 October 2017; accepted 18 November 2017
}

\begin{abstract}
Problem-based learning was an alternative learning model that can be implemented in a learning based on Reflective Pedagogy approach. Reflective Pedagogy not only prioritized knowledge aspect but also attitude aspect. This research was aimed to 1) describe the implementation of PBL using cycle of Reflective Pedagogy on Advanced Statistics learning and to 2) describe its influenced based on critical attitude, enthusiasm, and caring for others. The subject of this research was Psychology Student of class A. Data collection was gathered from the questionnaire and the results of student reflection. The result showed that the PBL phases could be well implemented in Advanced Statistics learning using Reflective Pedagogy. From the analysis was concluded that PBL gave influenced in good enough category based on critical attitude, enthusiasm, and caring for others.
\end{abstract}

Keywords: problem-based learning, reflective pedadogy approach, advanced statistics

\section{Introduction}

Education is one of the planned efforts to form intelligent people in personality, thinking, and will. As an educational institution, Sanata Dharma University always strives to educate young people to be intelligent and humanist. Ignatian pedagogy, later known as the Reflective Pedagogy Paradigm as the foundation for conducting learning activities, is believed to be able to develop students into professional person according to competence field, conscience, and compassion. The spirit is lived in conducting lectures in all courses.

Advanced Statistics Course is a compulsory subject for Psychology students of $2^{\text {nd }}$ semester. Statistics material itself is not new material, because the material has been introduced since elementary school, studied in junior high and high school, and pursued by Psychology students in the first semester as courses in Statistics. Thus, the material of Advanced Statistics lecture is a deepening of statistical material that discusses statistical methods, especially data analysis techniques on quantitative research. 
Students are also required to be critical both in solving problems and can criticize the completion obtained, and is expected to have a concern especially towards friends who have difficulty in understanding the material during the lecture and can establish good communication between friends and lecturers.

PBL (Problem-based learning) is one of the learning approaches designed to help learners develop their thinking skills, problem-solving skills, and intellectual skills (Arends, 2008). In the research of Masek \& Yamin (2011) explained that the steps in problem-based learning help learners in improving the ability of critical thinking. With these characteristics, PBL is theoretically very appropriate if applied in Advanced Statistics lectures.

Statistics are very synonymous with mathematics for people who do not wrestle the exact field are not easy to learn the material. The same thing is felt by most of the students of class A psychology when they are about to start their statistics in the previous semester. Students regard the material statistics as difficult, frightening, and complicated by countless calculations and formulas that cause anxiety and anxiety. This assumption greatly affects the enthusiasm of students in following the lectures, especially from involvement during the lecture.

During statistics last semester, not all students were eager to learn the material. In addition to the lecture hours during the day and previously there are also lectures, there are some passive students during the lecture. Nevertheless, some students look excited and always sit in the front row when the lecture takes place. Heterogeneous student characters make lecturers less able to facilitate all students, especially for students who are difficult and do not want to ask either to ask friends or lecturers. Looking at the ongoing lecture, enthusiasm in the lectures of statistics still needs to be improved. Student awareness of friends who have difficulty is still lacking because many who are proficient but not sharing with friends who have difficulty. Some students are also less than optimal in understanding because it is less critical in solving the problem so that errors occur calculates and apply the formula.

The implementation of PPR-based learning with active learning approach in Advanced Statistics is expected to facilitate students to be more enthusiastic about learning that can be seen from getting more involved in learning, increasingly responsible for the understanding of materials and tasks, the more excited in the lectures; able to be a critical and conscientious person; able to cooperate and increasingly care for friends who have difficulty (humanist). Learning that implements PPR with key elements of context, experience, reflection, action, and evaluation and by accommodating active learning models is able to facilitate students to be more enthusiastic in lectures, cultivate critical attitudes, and cultivate caring for others. Using these five elements is believed to be growing the aspect of competence, conscience, and compassion among students.

$3 \mathrm{C}$ values in Advanced Statistics lectures applying PPR will be more awake during lectures through specific models, methods, or strategies. It was discussed earlier that PBLs are theoretically very applicable in Advanced Statistics courses. On this basis the objectives of this research are: 1) to describe the implementation of PBL learning model based on Reflective Pedagogical 
Paradigm approach in Advanced Statistics Course and 2) to describe enthusiasm, critical attitude, and students' awareness toward others by implementing ProblemBased Learning Model).

The paradigm of Reflective Pedagogy, formerly known as the Ignatian Paradigm, consists of steps of experience, reflection, and action that interact constantly (Kanisius \& Community Studies and Development of PPR, 2012). Because the comprehensive PPR should pay attention to both the learning context and the pedagogical process and show that learners have completed a particular learning cycle, PPR contains five elements: context, experience, reflection, action, and evaluation.

The Paradigm of Reflective Pedagogy (PPR) is one of the pedagogy that is an approach to help the education needs as a whole and comprehensive, a way of lecturers assist students so that students develop into a whole and comprehensive person (Suparno, 2015). In the same book, it is said that the whole person in education is translated into $3 \mathrm{C}$ formulas, namely Competence, Conscience, and Compassion.

Competence in PPR is intended that students have the knowledge and skills according to their field. For psychology students, competence is needed to become a psychologist or psychiatrist. Conscience is needed for students to distinguish between good and evil. Compassion is a sensitivity and concern for each other and the surrounding environment. Conscience and compassion can be realized in students' attitude during lectures. It can be viewed from the enthusiasm, critical attitude, and concern for students to others.

Enthusiasm can be interpreted as a feeling of joy towards something that happens so as to generate a positive response. This positive response can be observed from the attention, concentration, consciousness, and willingness arising from self-will. When students are enthusiastic in lectures, students will have a positive response to learning, which can be seen from the attention of students in learning, student concentration during the lecture, and the involvement in the learning process (Kustanto, F, 2010). Khoerudin, J \& Sutarni, S. (2014) suggests that enthusiasm can be seen from the activities of students that is 1) pay attention to teachers, 2) ask, 3) and do the task.

Enthusiastic students will engage in lectures. These activities are: 1) ask, active and responsive as an effort to respond to learning, 2) pay attention to explanations of lecturers or other students as an effort to give attention to learning, 3 ) doing problem exercises and actively seeking solutions that show the existence of willingness in learning, 4) concentration in learning for example not affected by external situation, 5) have awareness in learning for example by first studying material that has not been submitted.

Critical attitude cannot be separated from critical thinking. Critical thinking is to think of testing, questioning, linking, evaluating all aspects of a situation or a problem. Paul, R \& Linda E. (2005) says that a person who thinks critically will be able to answer important issues well. He will think clearly and precisely. In addition, it can use abstract ideas to be able to model problem- solving effectively in order to find the truth for itself. Critical thinking ability of students in the course can be seen from how students behave during lectures, 
especially in an attempt to solve psychological problems involving hypothesis testing. Similar meaning is told by Herson (2009) who argues that critical attitudes are seen in the habit of seeking as much information as may be related to the field of study to compare the advantages, the suitability, the truth, and so on.

One of the things seen from people who are critical is being able to give opinions in an organized manner (Pusparatri, 2012). In addition, critical attitudes can also be demonstrated, among others, by 1) constantly asking for any change/novelty, 2) repeating the activities performed, and 3) meticulous by not ignoring the data through small (Herson, 2009).

Caring for others as one of compassion is identical with social caring attitude. Social care is one of the most important characters that teachers need to develop in learning. According to Retno Listyarti (2012: 7), social care is the attitude and actions that always want to provide assistance to other people and communities in need. According to KBBI (2008: 1036) social care is the attitude of heeding (apprehensive) something that happens in society.

In the social awareness, learners are expected to develop attitudes and actions that always want to provide assistance to others. The character of social care is needed learners as stock to live in a social environment. While the most important social element is the interaction between humans (S. Nasution, 1983: 14).

To realize enthusiasm, critical attitude, and caring for others can be implemented by applying the right learning model, one of them is PBL. Problembased learning (PBL) is one model of learning that confronts learners on unstructured, open-ended, or ambiguous practical issues (Fogarty, 1997). Herman (2007) in his research suggests that in PBL activities, learners' learning activities appear more prominent than the activities of teachers/lecturers/teaching educators. The learner shows a high level of enthusiasm and perseverance in solving problems, actively discussing and helping each other in groups, and not being awkward to ask questions or ask for guidance to teachers/lecturers/educators.

Margetson suggests that Problem-based learning (PBL) helps to improve lifelong learning skills in an open mindset, reflective, critical, and active learning (Rusman, 2001). In PBL, learners are faced with an issue that stimulates learners to analyze problems, estimate their answers, search for data, analyze data, and summarize answers to problems. Thus, problem-oriented learning by itself will train learners to think critically.

Arends (2008) outlines five major phases in problem-based learning (PBL). The phase is 1) Problem orientation; 2) Organizing learners to learn; 3) Assisting independent and group investigations; 4) Develop and present the work; and 5) Analyze and Evaluate the problem-solving process.

\section{Method}

This research is a qualitative descriptive study with the subject is the psychology student of A class in academic year 2016/2017 who taking Advanced Statistics learning.

Data on enthusiasm, critical attitude, and student awareness of others are gathered through questionnaires. Questionnaire of student response is a 
combination of students' critical attitude questionnaire, enthusiasm, and caring for others. Besides that, this research also using paper of students' reflection toconfirm the data.

Implementation of learning is analyzed descriptively by comparing between theory and the practice. Student response' questionnaire be analyzed descriptively by summing up each score obtained by students either for critical attitude, enthusiasm, and caring for each other then each score obtained is categorized in the following table.

Table 1. Conversion Score Student Response

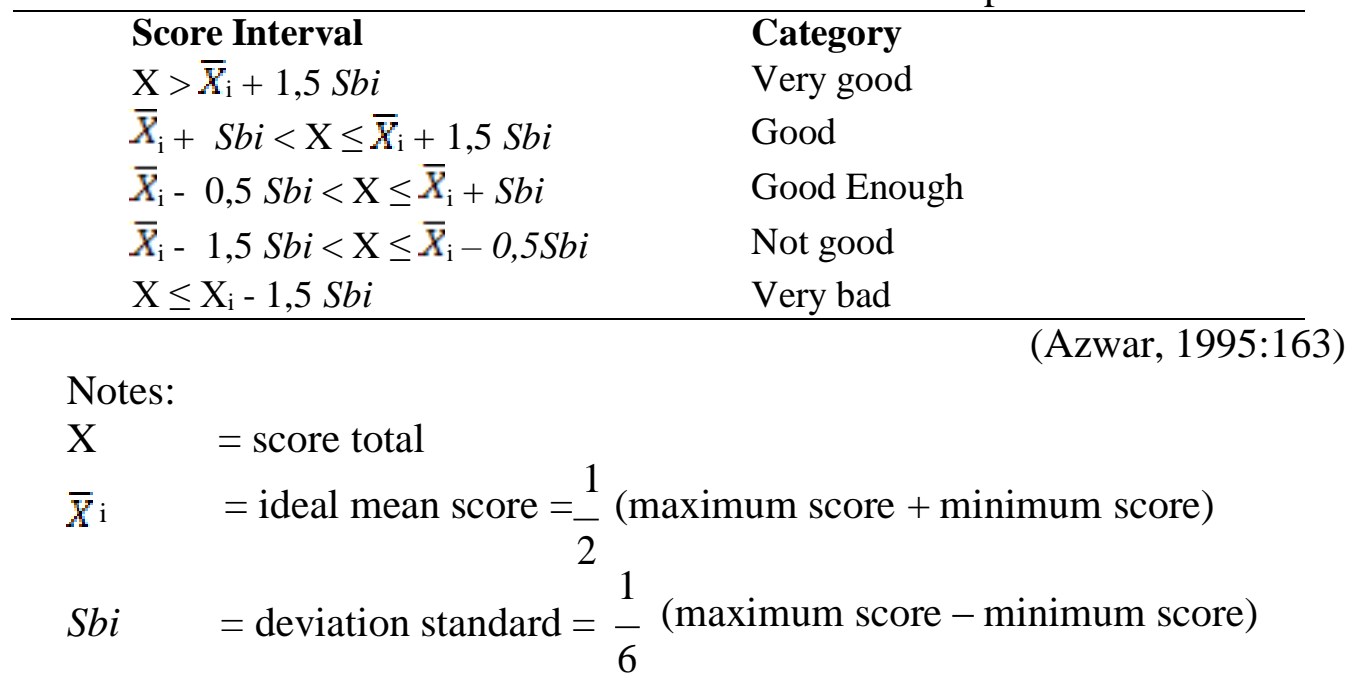

Each category of critical attitude, enthusiasm, and caring for each other is then searched for percentages. In additionm it will be calculated an average score on each variable then the average is categorized according to the table above.

The analysis of reflected document data is done qualitatively by the qualitative model of Miles and Huberman which includes three stages: 1) data reduction, 2) data presentation, and 3) drawing conclusions.

\section{Findings and Discussion}

Implementation of PBL

Reflective Pedagogy Paradigm-based learning can be implemented well indicated by the implementation of PI elements contains context, experience, reflection, action, and evaluation (Suparno, 2015). There is compatibility between theory and implementation from the learning model. PBL model consisting of phase: 1) giving orientation about the problem to the learner, 2) organizing learners, 3) assisting independent and group investigation, 4) developing and presenting artefacts and exhibit, and 5) analyzing and evaluating process (Arends, 2008) can be applied well. The results of the learning process using PBL can be seen in the following table.

Table 2. Resulf of Learning Process Using PBL

Group discussion process Some groups from eight group (8 problems)

discussed well, but there were 1-2 discussion 
IJIET Vol. 2, No. 1, January 2018

\begin{tabular}{cl}
\hline & groups less than the maximum (not all members \\
were enthusiastic).
\end{tabular}

The results of questionnaire analysis obtained data about students' critical attitude, enthusiasm, and caring for others. Each individual score of either critical attitude, enthusiasm, and caring for each other summed up then categorized. Each category is determined the percentage.

Table 3. Result of Student Response' Questionnaire

\begin{tabular}{lrrrrrr}
\hline Category & \multicolumn{2}{c}{ caring for others } & \multicolumn{2}{c}{ enthusiasm } & \multicolumn{2}{c}{ critical attitude } \\
\cline { 2 - 8 } & $\begin{array}{c}\text { Amount } \\
\text { of } \\
\text { Students }\end{array}$ & Percentage & $\begin{array}{c}\text { Amount } \\
\text { of } \\
\text { Students }\end{array}$ & Percentage & $\begin{array}{c}\text { Amount } \\
\text { of } \\
\text { Students }\end{array}$ & Percentage \\
\hline Very good & 2 & 5.56 & 3 & 8.33 & 2 & 5.56 \\
\hline Good & 11 & 30.56 & 3 & 8.33 & 12 & 33.32 \\
\hline Good enough & 22 & 61.11 & 28 & 77.78 & 20 & 55.56 \\
\hline Not good & 1 & 2.77 & 2 & 5.56 & 2 & 5.56 \\
\hline Very bad & 0 & 0 & 0 & 0 & 0 & 0 \\
\hline Total & 36 & 100 & 36 & 100 & 36 & 100 \\
\hline
\end{tabular}

The results for the average categories of each variable are as follows.

Table 4. Average Category of Critical Attitude, Enthusiasm, and Caring for Others

\begin{tabular}{ll}
\hline & \multicolumn{1}{c}{ Category } \\
\hline Critical attitude & Good enough \\
\hline Enthusiasm & Good enough \\
\hline Caring for Other & Good enough \\
\hline
\end{tabular}

The result of student's critical attitude indicates that included in the category is good enough. This is due to the results of student work is still a lot of studentswho are not careful in solving the problem. In fact, meticulous is one of the indicators that determine the critical attitude of students (Herson, 2009). 
The enthusiasm of psychology students both the majority and the average included in the category is good enough. This result is supported by the results of reflection which states that the involvement of students is less than the maximum and the tendency to just listen and not actively ask or just rely on group members who already understand. Enthusiasm can be seen from involvement in the learning process (Kustanto, F, 2010) and also actively ask (Khoerudin, J \& Sutarni, S., 2014). Student awareness of others from the results of student reflection has been awakened.

From the results of student reflection, it is found that most of the students are happy with the implementation of discussion method in PBL as the following table.

Table 5. Result of Student Reflection After Study using PBL

\begin{tabular}{|c|c|}
\hline Positif Point & Negative Point \\
\hline Happy with the discussion & Discussion methods are less \\
\hline method as it helps to gain more & effective. Lecturers should explain \\
\hline understanding. & clearly, give examples, give questions \\
\hline - $\quad$ Presentation methods make it & and practice (discussion). \\
\hline understandable. & - $\quad$ Ineffective if one group is not \\
\hline $\begin{array}{l}\text { - Gives a sense of wanting to do } \\
\text { more. }\end{array}$ & $\begin{array}{l}\text { equal in ability, difficult to work } \\
\text { together } 4\end{array}$ \\
\hline $\begin{array}{l}\text { - Can better understand, help, } \\
\text { with each other. }\end{array}$ & $\begin{array}{l}\text { Confusing students because of } \\
\text { frequent differences in views } 2\end{array}$ \\
\hline $\begin{array}{l}\text { - Patience to explain to friends } \\
\text { who do not understand. }\end{array}$ & $\begin{array}{l}\text { - Students were just relying on } \\
\text { who can already. }\end{array}$ \\
\hline - $\quad$ More effective because they & - $\quad$ Discussion can proceed as \\
\hline can ask each other and exchange & long as the division of the group is fair \\
\hline opinions. & - $\quad$ Discussion takes a long time \\
\hline $\begin{array}{l}\text { - Believe in friends and } \\
\text { cooperation }\end{array}$ & \\
\hline $\begin{array}{l}\text { Value of tolerance, empathy, } \\
\text { sympathy, respect for opinion, and } \\
\text { caring }\end{array}$ & \\
\hline $\begin{array}{l}\text { - Responsibility and training } \\
\text { always strive. }\end{array}$ & \\
\hline Learn to organize well & \\
\hline To be able to follow the need to & \\
\hline $\begin{array}{l}\text { learn to understand the material first } \\
\text { (better prepare yourself) }\end{array}$ & \\
\hline $\begin{array}{l}\text { - More active and enthusiastic } \\
\text { learning }\end{array}$ & \\
\hline
\end{tabular}

The result of reflection during the learning process is many students who received positive benefits and some negative. Most say that the discussion model can help understanding because it becomes more clear when described by friends. However, 9 of the 36 students $(26 \%)$ did not fully agree with the method of discussion. The causative factor is a group friend who is less cooperative, not if too many differences of opinion leads to more confusion, and if a friend who does 
not understand difficult to understand the material, and depends on the material discussed.

In addition to happy with the method of discussion, students can also build noble values in lectures such as cooperation, mutual help, can appreciate friends, patience, and mutual trust. However, when asked about the involvement in the lectures, especially the discussion, not all students expressed certainty involved in the discussion. Although many claims to be involved, the involvement depends on group members. Many students just listen without asking or just rely on friends who already understand. This is an indication that causes less maximal student enthusiasm.

\section{Conclusions}

Based on the results of research that has been done the researchers obtained some conclusions as follows.

1. The PBL-based learning phases of the Reflective Pedagogy Paradigm in Advanced Statistics courses that are composed can be carried out well.

2. The student's enthusiasm, critical attitude, and student's concern for others are quite good.

PBL model, in addition can be applied in advanced statistics courses can also be applied to other courses tailored to the characteristics of the course.

\section{References}

Arends, R.I. (2008). Learning to teach: belajar untuk mengajar ( $7^{\text {th }}$ ed.). (Translated by Helly Prajitno Soetjipto and Sri Mulyantini Soetjipto). New York: McGraw Hill Companies Inc.

Azwar,S. (1995). Sikap manusia teori dan pengukurannya. Yogyakarta: Pustaka Pelajar

Fogarty, R.(1997). Problem based learning \& other curiculum models for the multiple intelligences classroom. New York: Sky Light Professional Development.

Herman, T. (2007). Pembelajaran berbasis masalah untuk meningkatkan kemampuan berpikir kritis matematis tingkat tinggi siswa Sekolah Menengah Pertama. Journal Education, 1,1.

Herson, A. (2009). Penilaian Sikap Ilmiah dalam Pembelajaran Sains. Jurnal Pelangi Ilmu, 2(5).

Kanisius \& Komunitas Studi dan Pengembangan PPR Yogyakarta. (2012). Paradigma pedagogi reflektif: Mendampingi peserta didik menjadi cerdas dan berkarakter. Kanisius: Yogyakarta.

Kustanto F. (2010). Peningkatan Antusiasme Siswa dalam Pembelajaran Matematika melalui Metode Participatory Learning pada Pokok Bahasan Bangun Ruang Sisi Datar. Skripsi UMS. (Online) available in http://eprints.ums.ac.id/11673/1/COVER_\%2B_BAB_I.pdf\#page=7\&zoom $=$ auto,-20,273

Masek, A., \& Yamin, S. (2011). The effect of problem based learning on critical thinking ability: A theoretical and empirical review. International Review of Sciences and Humanities, 2(1), 215-221. 
IJIET Vol. 2, No. 1, January 2018

Paul, R., \& Linda E.. (2005). The Miniature Guide to Critical Thinking "CONCEPTS \& TOOLS". The Foundation of Critical Thinking: California

Pusparatri, R.K.D. (2012). Strategi Pembelajaran Berbasis Masalah untuk Meningkatkan Kemampuan Berpikir Kritis Siswa. Jurnal Ilmiah Guru “COPE”, Nomor 02/Tahun XVI/November 2012. (online) Retrieved from http://download.portalgaruda.org/article.php?article=307174\&val=464\&title $=$ STRATEGI\% 20PEMBELAJARAN\%20BERBASIS\%20MASALAH\%20 UNTUK\%20MENINGKATKAN\%20KEMAMPUAN\%20BERPIKIR\%20 KRITIS\%20SISWA

Rusman. (2001). Model-model pembelajaran mengembangkan profesionalisme. Jakarta: Rajawali Pers

Suparno, P. (2015). Paradigma Pedagogi Refleksi (PPR). Yogyakarta: Universitas Sanata Dharma 